Bešter, R., \& Medvešek, M. (2015). Immigrant languages in education: The case of Slovenia. Ethnicities, 15(1), 112-133.

Ethnicities published online 7 August 2014

DOI: $10.1177 / 1468796814546911$

https://journals.sagepub.com/doi/full/10.1177/1468796814546911

\title{
Immigrant languages in education: The case of Slovenia
}

\begin{abstract}
This article deals with the question of importance of maintaining immigrant languages and focuses on the opportunities for immigrants in Slovenia to learn their mother tongues in school. It presents the legal and formal framework determining the scope for the development of immigrant languages within the educational system in Slovenia. It also touches upon the implementation of legal and formal provisions in practice and the attitudes of immigrants and their descendants as well as teachers toward the learning and use of immigrant languages in education. Research has shown that the desire among immigrants for the preservation of their mother tongues exists, but due to various objective and subjective reasons not much has been done so far to achieve this goal.We argue that the maintenance of immigrant languages is important and that a reconsideration of educational policy in this regard would be in place.
\end{abstract}

Keywords

Bilingual education, education, immigrants, immigrant languages, mother tongue, Slovenia

\section{Introduction}

With regard to the integration of immigrants and their descendants, society's attention, and often that of the immigrants themselves, is directed mainly toward mastering the language of the host country - little attention is paid to the learning and development of immigrant languages. This is the situation in Slovenia. Until now, hardly any attention has been paid to immigrants learning and preserving their mother tongue, be it in research ${ }^{1}$ or in the realm of political regulation. In recent years, the situation has shown signs of change, but only incrementally. Certain policies have been adopted in the field of education that focus attention on the creation of suitable circumstances for immigrants learning their mother tongue. Moreover, immigrant communities themselves, particularly the larger ones from the successor states of the former Yugoslavia, have begun calling upon the state to provide better conditions for the development of their languages (Baltić, 2010: 154; Ivanjko, 2007: 59-61).

Due to migration flows, Slovenia is increasingly facing a growing diversity of populations with different ethno-linguistic origins. The social and political status of ethno-linguistic minorities in Slovenia differs substantially due to historical reasons and the origin of their minority status (traditional versus migrant minority communities). The attitudes of the majority population toward individual minorities and the right to preserve their ethnic identity (including language as a feature of this identity) also differ. Public opinion polls (Komac, 2007; Komac and Medvešek, 2005: 207-236; Zavratnik, 2012; Zavratnik Zimic et al., 2008) carried out in Slovenia show that there are differences in the understanding of language as a cultural or as educational right. These studies also show that the majority population does not oppose the 
right of immigrants to use their mother tongue at home and in cultural associations, i.e. in their private life. Things change when the discussion on learning and using immigrant languages moves to the public sphere.

The main research questions we will deal with in this article are: Why is the preservation of immigrant languages important? What does research say about the effects of including (or not including) minority languages in the educational process? How is the learning of immigrant languages ${ }^{2}$ implemented in Slovenia, especially in the public educational system? With respect to the situation in Slovenia, we will focus on the languages of the ethnic communities from the former Yugoslavia, the largest and the most established immigrant communities in Slovenia. Arguments for the learning of (and in) immigrant languages will be presented, as well as the current situation regarding the legal and formal framework that determines the status of these languages and their scope for development in the Slovenian educational system. We will also talk about the implementation of legal and formal provisions in practice and the attitudes of immigrants and their descendants toward the learning, use and status of their mother tongues in Slovenia.

\section{The linguistic composition of Slovenia's population}

According to the 2002 census, Slovene is not the mother tongue of approximately $10 \%$ of Slovenia's population, while for 3\% the mother tongue is not known. This share has been increasing over recent decades - in overall numbers, as well as in the variety of languages. The main reasons for the changing linguistic composition have been migration flows (Komac and Medvešek, 2005: 93-118).

After Slovenia's independence, in spite of major political changes in the Western Balkans and Slovenia's accession to the European Union, the structure of immigrant flows to Slovenia (with respect to country of origin) did not significantly change. The greatest number of immigrants still comes from the countries succeeding the former Yugoslavia, particularly Bosnia and Herzegovina.

Our knowledge about the linguistic composition of Slovenia's population is largely based on census results. We should bear in mind that, while population censuses offer a rich set of data, they do have limitations that make them contribute to the creation of a specific image of social reality. Census statistics classify individuals into neat categories, which assume the existence of a common collective identity, rather than view social links as complex and social groupings as situational (Kertzer and Arel, 2002: 5-6). Notwithstanding this shortcoming, the census is a valuable tool for the presentation of the multicultural composition of society and the basis for the development of language and education policies (Broeder and Extra, 1999). With each census since 1971, the collected data point to an increasing variety of mother tongues among Slovenia's population (see Table 1).

The advantage of past censuses was that they enabled inhabitants to declare their mother tongue themselves. With the transition to the register-based census in 2011, the figures regarding the linguistic composition of Slovenia's population are no longer collected. We now dispose only of data such as the first country of residence, country of immigration, citizenship, etc. The classification of a certain part of the population as members of a linguistic community on the basis of their origin or the origin of their parents is much more problematic. More recent data (SORS, 2011) show that among the population of Slovenia on 1 January 2011 there were 228,588 persons whose first residence was abroad (11\% of the population). Among those, $87 \%$ had their first residence in the successor states of the former Yugoslavia. We can thus assume that in Slovenia there are a significant number of people whose mother tongue is Croatian, Serbian, Macedonian, Bosnian, or Albanian. 


\section{Why is it important to nurture immigrant languages?}

There are a number of reasons why the preservation/learning of immigrant languages is important and beneficial. Proponents of preserving mother tongues of different minority ethnic communities cite various arguments in support of this. Some deal with language rights as human rights or the rights of ethnic minorities (May, 2011; Skutnabb-Kangas, 2004). Some highlight the special importance of the mother tongue for the individual's identity. Others stress the importance of education in the mother tongue, which is said to contribute to children's better school performance and to their overall successful development (Cummins, 2001). Some see the preservation of migrant languages as an important factor in raising economic opportunities for individuals and society (Grin, in Skutnabb-Kangas (2004)). Hereinafter we shall pay closer attention to some of the above-mentioned arguments, relating them to the situation of immigrant languages from the territory of the former Yugoslavia in Slovenia.

Table 1: Population according to mother tongue, ${ }^{3}$ censuses $1971-2002$

Table I. Population according to mother tongue, ${ }^{3}$ censuses I97|-2002.

\begin{tabular}{|c|c|c|c|c|}
\hline $\begin{array}{l}\text { Mother tongue } \\
\text { Total }\end{array}$ & $\begin{array}{l}1971 \\
1,727,137\end{array}$ & $\begin{array}{l}1981 \\
1,838,381\end{array}$ & $\begin{array}{l}1991 \\
1,913,355\end{array}$ & $\begin{array}{l}2002 \\
1,964,036\end{array}$ \\
\hline Slovene & $1,627,462$ & $1,682,381$ & I,69।,547 & $1,723,434$ \\
\hline Italian & 3,471 & 2,854 & 3,882 & 3,762 \\
\hline Hungarian & 10,562 & 9,354 & 8,720 & 7,713 \\
\hline Roma & 969 & 1,382 & 2,752 & 3,834 \\
\hline Albanian & 1,112 & 2,058 & 3,903 & 7,177 \\
\hline English & - & - & 75 & 345 \\
\hline Arabic & - & - & - & 130 \\
\hline Bulgarian & - & 92 & 131 & 159 \\
\hline Bosniak & - & - & - & 31,499 \\
\hline Czech & 515 & 535 & 445 & 421 \\
\hline Montenegrin & - & - & - & 462 \\
\hline French & - & - & 73 & 206 \\
\hline Croatian & 41,014 & - & 50,699 & 54,079 \\
\hline Croatian-Serbian & 1,106 & - & 3,208 & 126 \\
\hline Chinese & - & - & - & 216 \\
\hline Macedonian & 1,505 & 3,068 & 4,525 & 4,760 \\
\hline German & 1,322 & 1,023 & 1,093 & 1,628 \\
\hline Polish & 240 & 264 & 309 & 267 \\
\hline Romanian & - & 235 & 295 & 251 \\
\hline Russian & 351 & 238 & 229 & 766 \\
\hline Slovak & - & 145 & 163 & 294 \\
\hline Serbian & 16,074 & - & 18,123 & 31,329 \\
\hline Serbo-Croatian & 16,607 & - & 80,325 & 36,265 \\
\hline Serbocroatian & - & 128,449 & - & - \\
\hline Spanish & - & - & - & 129 \\
\hline Turkish & - & 112 & 172 & 226 \\
\hline Ukrainian & - & 158 & 171 & 399 \\
\hline Other & 1,083 & 658 & 1,316 & 1,843 \\
\hline Unknown & 3,744 & 5,375 & 41,199 & 52,316 \\
\hline
\end{tabular}

Source: Šircelj (2003: 97). 
The link between language and ethnic identity is a widely debated topic. While primordialist views of ethnicity as fixed and determined by objective cultural characteristics-language being one of them - are today widely discarded, there are different opinions on the importance of language as an (ethnic) identity aspect. Some authors (e.g. Coulmas, 1992; Eastman, 1984; Edwards, 1985, 1994) argue that language is just a surface feature of ethnic identity, while others (Blackledge and Creese, 2009; Fishman, 1991; May, 2000, 2008) put forward the importance of identity-language links. May (2000: 373, 2008: 129), while agreeing that language is not an inevitable feature of ethnic identity, argues that it is nevertheless an important one. In our view language could in many cases be described as a very important feature of immigrants' ethnic/cultural identity. When moving to a different cultural environment, immigrants are faced with situations where there are usually few possibilities for them to enjoy and nurture their culture, their way of life. They need to adjust to the different cultural norms and expectations of the new society, and their identity is inevitably exposed to gradual transformations. In such a situation language might (at least at the beginning) be the most solid feature of one's identity. When everything around is new and strange, language - the mother tongue - may present a core foundation around and through which a person builds his selfawareness as well as the awareness of everything around him, making sense of new circumstances and dealing with the challenges brought by the new cultural environment. If we consider a language to be a part of a person's identity, this should justify the claim that the government should pay attention to mother tongue learning for immigrant children (cf Hajer and Meestringa, 1991: 73). According to Nowak-Fabrykowski and Shkandrij (2004: 25), the children of immigrants in particular, who were not born in the host country but have moved there should have the opportunity of preserving the "original symbolic world (based on the mother tongue and culture) and the simultaneous right to integrate into a new linguistic dealing with cultural content." This is so particularly because the combination of the two symbolic worlds (languages and cultures) is an important element of the identity of the descendants of immigrants and their personal growth (Nowak-Fabrykowski and Shkandrij, 2004: 26). Later in the process of integration the importance of the mother tongue for immigrants might change, depending on the circumstances (the size of the immigrant community, the importance of the language as a feature of ethnic identity of that community, the immigrant community's claims for the preservation of their language, the (economic) value of the language within the broader society, etc.). Over the course of three or more generations, immigrant ethnic minorities often shift to the language of the mainstream society in order to enhance their integration and social mobility within the host country (May, 2008: 135; cf Isajiw, 1993). They may nevertheless preserve their ethnic identity, as some authors argue (Eastman, 1984), but in our opinion it is more often the case (as presented by Kroon, 1990: 424-425) that language shift eventually leads to language loss and is connected to the loss of ethnic group cohesion and eventually the loss of "original" ethnic identity.

It is difficult for a migrant minority community to maintain its language if this language does not have adequate social support and social, economic, and political status, and its use is limited to the circle of the family (Fishman, 2001). The loss of language and ethnic identity is by no means unproblematic, as it may seem at first glance. It can have different negative psychological and sociological consequences. It can lead to excessive assertion of identity which, as Maalouf et al. (2008: 11) write "often stems from a feeling of guilt in relation to one's culture of origin, a guilt which is sometimes expressed by exacerbated religion-based reactions.' From this perspective, facilitating migrants' access to learning their native languages and allowing them to maintain their linguistic and cultural dignity might also be a powerful antidote against fanaticism (Maalouf et al., 2008: 11). 
Immigrant communities from the former Yugoslavia in Slovenia express a desire to maintain their ethnic identity and they make requests to the government to provide opportunities for developing their cultural activities and learning their languages (see Baltic' , 2010: 154). From this we can conclude that these communities consider language as an important part of their ethnic identity and that they want to keep it.

\section{Easier learning and better school achievements through bi/multilingual education}

Notwithstanding the importance that we ascribe to language as an identity aspect, languagethe mother tongue - plays an important role in the educational development of a child; the mother tongue is more than just a communicative tool. Cummins (2001: 3) writes that " $[t]$ he research is very clear about the importance of bilingual children's mother tongue for their overall personal and educational development." It is through their mother tongue that children most easily acquire "the basic conceptual skills which form the basis for all future learning, be it linguistic in nature or not" (Commission of the European Communities, 1994). Trudell et al. (2012: 20) argue that the "[u]se of the child's mother tongue for learning has been shown to accelerate the learning process significantly beyond the normal rate for schools using the official language as the medium of instruction.' Other studies (see Ball, 2011; Lutz, 2007) also show that the learning of the mother tongue and particularly education in the mother tongue or bilingual education positively affects children's academic performance. The results of a study carried out by Thomas and Collier (2002) show that the longer a child is educated in his or her mother tongue and at the same time gradually learns another language, the better is his or her academic performance.

The results of the international survey PISA 2003 (OECD, 2006) show that immigrant students usually under-perform in school compared to students who are native speakers, even when they live in comparable socioeconomic conditions. This is true also for Slovenia (Kolednik, 2010). The lower academic achievements of immigrant children are to a large degree ascribed to the bad command of the language of instruction in the host country. The demands for more efficient strategies of teaching the host country's language to immigrant children are usually put forward with the aim of providing equal opportunities to immigrant children in education. Comparative international studies show that immigrant children who speak a foreign language at home receive lower achievement scores than other children (Schnepf, 2004: 26). Similarly, Kolednik's (2010: 145) study on the academic achievements of immigrant students in Slovenia shows that immigrants who use Slovene in communication within their families do better than those who speak non-Slovene languages at home. This might lead to the conclusion that fostering the use of the host country's language, even within immigrant families, is one way of facilitating immigrant children's success in school. We believe that such conclusions are incorrect and might even be damaging for the cause. While good command of the host country's language is certainly important for immigrant children, facilitating its use at the expense of the children's mother tongue might not be the best solution for their overall development. None of the above-mentioned studies deals with the question or possibility of improving the immigrant children's school results by providing them with the opportunity of studying (and being tested) in their mother tongue, while also intensely learning the host country's language as a second language. In our opinion this would be a much better way of providing equal opportunities for immigrant children and the full development of their potential. 


\section{Integration aspect}

One of the most important indicators that are usually considered when assessing the success of immigrants' integration is their knowledge of the language of the host country. Much less attention is paid to the knowledge of immigrant languages. Sometimes in public discourse immigrant languages are seen as a source of problems and barriers to the integration process (Bauböck, 2002: 181), while the knowledge of the majority language is considered a source of enrichment and a prerequisite for integration (Extra and Yağmur, 2004: 22). Yet the goal of the integration process, as we understand it, should be to prepare immigrants for full participation in the society in which they live. As Hajer and Meestringa (1991: 73) point out, we have to take into account that immigrants "live within two different cultures of differing status, neither of which they can afford to neglect." And in order to be able to participate fully in both and also to find a personal balance between the two, communicative competence in both the majority language and their native language is essential (Hajer and Meestringa, 1991: 72). Therefore in order to enhance the integration and full participation of immigrants in all parts of the society to which they belong, the host country should enable them to learn and use both languages without this being an obstacle to their social mobility.

In the opinion of some researchers (e.g. Cummins, 2001; Skutnabb-Kangas, 2004), proficiency in the mother tongue increases the ability to learn foreign languages. However, there are contrasting opinions about the relationship between a child's knowledge of his or her mother tongue and knowledge of another language. Christensen and Stanat (2007: 2) say that the empirical support for the assumption that students can become proficient in a second language only if they are already proficient in their first language is rather weak. Tosi (2004: 2) arrived at a similar conclusion and pointed out that due to different degrees of bilingualism and different circumstances we cannot talk about the benefits of bilingualism in general, but it makes more sense to evaluate each bilingual situation separately. Krashen (1997: 4) draws attention to the fact that the greatest critics of bilingual education (e.g. Rossell and Baker, 1996), "do not claim that bilingual education does not work; instead, they claim there is little evidence that it is superior to all-English programs. Nevertheless, the evidence used against bilingual education is not convincing." 4 In his overview of studies of bilingual education and criticism of them, Cummins (2000) also arrives at similar conclusions. By contrast, Robinson (2005: 16) points out the negative impacts that a lack of multilingual education has for the integration process. Among other things, he argues that a policy using only a mainstream or official language as the medium of instruction results in increased marginalization from education for those already suffering disadvantage (as immigrants often do). It reflects lack of respect for diversity and sends out strong messages of inferiority to those speaking nonmainstream languages (Robinson, 2005: 16).

Slovenia has a wealth of experience with bilingual education, but this is only provided for the Italian and Hungarian national minorities in the ethnically mixed territories (see Novak Lukanovič , 2000, 2010; Novak Lukanovič and Limon, 2012). Other ethnic groups, some of them much larger than these two minorities, do not have the possibility of bilingual education or education in their mother tongue. This difference is due to historical reasons - the Italian and Hungarian minorities coming into being as the result of borders changing after WW1 and WW2. In compensation, these two communities were granted a whole range of special minority rights on the territory where they traditionally reside. The former Yugoslav ethnic communities, on the other hand, settled in Slovenia as internal (mostly economic) immigrants within the then common state, Yugoslavia. They were never considered as national minorities and they did not have any special minority rights. Nevertheless, before Slovenia's independence in 1991 there was one elementary school in Ljubljana with a few classes in which Serbo-Croatian was the 
language of instruction. These classes were created for, and attended by, children of parents of non-Slovene nationality who due to the nature of their work (for example in the military) were mostly temporarily settled in Slovenia - at that time a Yugoslav republic. In addition, the SerboCroatian language was taught as a 1-year obligatory subject for all pupils in Slovene primary schools. After Slovene independence this subject and the Serbo-Croatian classes were abolished (Medvešek and Bešter, 2011: 228). In the last decade the conditions for learning the languages of the former Yugoslavia in Slovene primary schools have gradually been re-created, but in a different way and to a limited extent. The study of these languages is being offered in the form of special (optional) subjects as foreign languages in the last 3 years of elementary school. This model of teaching immigrant languages is not best suited to immigrants wishing to learn and preserve their mother tongue, as will be explained in more detail below. Nevertheless, reinclusion of these languages in the educational system represents a small, positive step in confirming the value of immigrants' cultural and linguistic backgrounds.

\section{Economic aspects}

Economic participation and success are often important factors guiding a person's behavior in society. This also relates to the use of language. In many cases immigrants shift to the majority language in order to succeed in the mainstream society.

As Kroon (1990: 424-425) writes,

the general tendency seems to be that as soon as members of ethnic minority groups reach a certain level of proficiency in the dominant language they start using it, also in intraethnic communication. Then the ethnic group language [...] passes into disuse and the shift to the dominant language takes place.

This, as Kroon (1990: 425) puts it, "seems to be the price immigrant ethnic minority groups have to pay for social mobility in the dominant society." But this does not necessarily need to be the case since the knowledge of the ethnic minority language might also be seen as an asset in the economic field. The ability to be fluent in a number of languages opens up additional opportunities in education and in professional development, as well as improving an individual's opportunities in the labor market. Authors studying the value of linguistic competence in several languages list various "market and nonmarket values" of multilingual competence (for a review see Skutnabb-Kangas, 2004). For example, Franc, ois Grin (in Skutnabb-Kangas, 2004: 15-16) differentiates between market and nonmarket values of multilingual competence for private and social purposes. If at this point we consider only market values, Grin (in Skutnabb-Kangas, 2004: 16) lists the following examples of private market values: "1. net earnings differentials; 2 . wider choice of jobs; 3 . more interesting jobs; 4. access to lower prices; and 5. quicker/cheaper access to information." These are some of the individual benefits of multilingualism, but it also has a value for societies. Speaking of social market benefits in terms of the relationship between creativity, innovation, and investment, Skutnabb-Kangas (2004: 16) argues that high levels of multilingualism can enhance creativity whereas homogenization of various kinds is a market handicap. Multilingualism can also open up more possibilities for foreign exchange, benefiting the whole society. Promotion of immigrant languages in this respect presents not solely a linguistic market value, but brings along additional benefits, with immigrants knowing not only the language of their country of origin, but also the cultural patterns (norms, customs, values, etc.).

It might be argued that from the economic point of view not all languages are equally important and worth promoting, so let us take a look at the situation in Slovenia with regard to the languages of immigrants from the former Yugoslavia. The countries of the former Yugoslavia 
present important business regions for Slovenia. Taken together, the share of Slovene exports to these countries, although declining in recent years, still represents more than $10 \%$ of total Slovene exports (data for 2013 (SORS, 2014)). Slovenia exports more to only Germany and Italy. As was recently stated at a meeting of Slovene and Serbian entrepreneurs in Ljubljana, one of the biggest obstacles for good economic cooperation between Slovenia and the countries of the former Yugoslavia is nowadays the language barrier (Žurnal24.si, 2014). From the economic point of view, it is thus irrational to allow the knowledge of the mother tongues of immigrants from the former Yugoslavia to be forgotten, which is what happens sooner or later when a language is not used. Looking from the viewpoint of encouraging bilingualism, investment in the preservation and improvement of the knowledge of the immigrants' mother tongues is probably smaller than that in the learning of other languages.

\section{Immigrant language learning in Slovenia}

The rest of this paper will be devoted to an analysis and presentation of the situation regarding the teaching and learning of immigrant languages in Slovenia. For the reasons already mentioned, particular attention will be paid to the languages of the immigrant communities from the former Yugoslavia.

\section{Some methodological aspects of the research}

The case study of immigrant languages in Slovenia is based on analysis of the relevant legislation and other documents that represent the legal foundations for education in Slovenia, and on an analysis of the empirical data collected in two studies: Perceptions of Slovenia's Integration Policy I-PSIP I (2002-2004), and Integration of Third-Country Nationals in Slovenia-ITCNS (2008-2009). ${ }^{5}$ In both studies, we dealt with situations and problems faced by immigrants and their descendants in the integration process. We also discussed the attitudes of immigrants and their descendants to the use and learning of their mother tongues. By analyzing the results of these studies (which have used different research methods) we pursue a pluralistic, methodological approach (see Della Porta and Keating, 2008).

In the PSIP I, which was based on a quantitative approach, a sample was created that included members of all the ethnic communities from the former Yugoslavia in Slovenia. Thus, the sampling frame necessary for carrying out probability sampling was defined as the inhabitants of the Republic of Slovenia who, after Slovenia gained its independence, submitted an application for Slovene citizenship. The sample included 1163 survey participants, among whom $62.6 \%$ were immigrants who had moved to Slovenia when they were over 15 , and $37.4 \%$ were the descendants of immigrants. A structured questionnaire which included 94 questions, mainly of a closed type, was used. The survey participants were asked to fill in a questionnaire sent to them by post, asking about their inclusion in different areas of everyday life, including school, and about their attitude to language.

In the ITCNS study we analyzed the integration process of immigrants focusing on two aspects: the perceptions of immigrants and the attitude of the majority population toward immigrants. We conducted 22 in-depth, semistructured interviews with immigrants who had immigrated to Slovenia between 1992 and 2008. The sample was created using the nonrandom snowball method. The attitude of the majority population was assessed through additional interviews and focus groups with selected populations from the field of health, education, and public administration that are in direct everyday contact with immigrants. In the field of education, we carried out two focus groups - one in a primary school and one in a secondary school. In addition, we conducted individual interviews with senior civil servants at the Ministry of Education, Science and Sport (MESS), who create educational policy. 


\section{Legal provisions for learning immigrant languages in the educational system}

The possibility of learning their mother tongue for children whose mother tongue is not Slovene is guaranteed by Slovenia's legislation. The Elementary School Act (Article 8) states that

[f]or the children who reside in the Republic of Slovenia and whose mother tongue is not Slovene, [...] lessons in Slovene language and culture shall be organized upon their inclusion in elementary school, and in cooperation with the countries of origin, also lessons in their mother tongue and culture.

These legal provisions refer both to children who are Slovene citizens and those who are not. In contrast, the provision which has since 2008 guaranteed the financing of the teaching of the (non-Slovene) mother tongue in primary and secondary schools from the state budget refers only to children who are foreign citizens (Article 81 of the Organization and Financing of Education Act).

Teaching immigrant children their mother tongue is also encouraged by the Strategy of the Inclusion of Immigrant Children, Pupils and Students in the Education System in the Republic of Slovenia, adopted in 2007. Two years later, measures for encouraging the learning of the mother tongue were envisaged in the Guidelines for the Education of Immigrant Children in Nurseries and Schools (National Education Institute of the Republic of Slovenia, 2009) and in 2012 in the Guidelines for the Inclusion of Immigrant Children in Nurseries and Schools (National Education Institute of the Republic of Slovenia, 2012). In 2011, a new White Paper on Education in the Republic of Slovenia (Ministry of Education and Sport, 2011) was adopted, which again supported the idea of pupils and students whose mother tongue is not Slovene learning their mother tongue. Schools should offer the learning of immigrant languages in the form of elective subjects within a specific curriculum (Ministry of Education and Sport, 2011: 34). In addition, language lessons in Slovene schools should include (along with intercultural and multilingual awareness), in a suitable fashion, the languages that are not a part of the curriculum but are present in the pupils' environment, e.g. their mother tongue (Ministry of Education and Sport, 2011: 34-35). The need to encourage the learning of immigrant mother tongues and other languages of minorities is also recognized in the Resolution on the National Program for Language Policy 2014- 2018 (Resolucija o Nacionalnem programu za jezikovno politiko 2014-2018, 2013), which says that, with regard to the languages of minorities and immigrants, Slovene policy is based on the assumption that a well-developed linguistic proficiency in the first language is one of the fundamental conditions for the development of language proficiency in Slovene. But no specific measures to provide immigrants with an opportunity to develop fluency in their mother tongue have yet been drawn up. In spite of this, we can say that at the political and legal level, Slovenia supports the teaching and learning of the mother tongue of those children whose mother tongue is not Slovene. But what is the situation in practice?

\section{Implementation of the legislative provisions}

There are different models of integrating an immigrant language into the school system (see Christensen and Stanat, 2007: 4). The model practiced in Slovenia can be labeled "immersion." Its characteristic is that the teaching of immigrant languages is not given special attentionimmigrant students are taught in the regular classroom and they receive (or not) some additional instruction aimed at increasing proficiency in the language of instruction over a limited period of time (Christensen and Stanat, 2007: 4). 
Organized teaching of immigrant languages in Slovene schools is the exception rather than the rule and it does not have an established and systemically determined form. At first glance, this is justifiable from financial and the organizational points of view. The objection often heard is that it is difficult to ensure the teaching of so many immigrant languages within the educational system. Such an argument, as Robinson (2005: 17) argues, reflects a view "that language diversity is a problem to be solved, rather than an asset to be used" and that "some language communities are more important than others." This is the "perspective of the national official, member of the elite, and not that of the local communities with their daily communication patterns', (Robinson, 2005: 17).

Even when we agree in principle that bilingual education is in the best interests of every immigrant child, in practice the implementation of this principle brings about various organizational challenges. The question of where to draw a line and what preconditions have to be met for a migrant language to be included in the educational system remains open. Nevertheless, we argue that it is definitely important and necessary to evaluate and consider the knowledge of other languages possessed by immigrant children and recognize this knowledge as an asset rather than a hindrance. It is also necessary to at least explore the possibility of enabling immigrant communities to learn their mother tongues in school. In particular when these communities themselves express demands for this, as is the case with the communities from the former Yugoslavia in Slovenia.

Immigrant language lessons in Slovenia today take three forms. Children can learn the languages voluntarily, in their free time within cultural societies organized by immigrant communities. We do not have data on how many immigrant communities organize language courses and how many children attend them. Baltić (2010: 155) argues that "[e]xperience with independently organized mother tongue learning has shown that it is difficult to ensure outside the school system a largescale response from the children."

Children can also learn immigrant languages as an extracurricular activity in school, which is also voluntary and takes place in pupils' free time. In the school year 2012/13, extracurricular Albanian, Bosnian, Croatian, Dutch, German, Macedonian, Russian, and Serbian lessons took place at 11 primary schools in Slovenia and were attended by 275 children (Bronka Štraus, 2013, personal communication). For a number of years, the MESS has supported the implementation of extracurricular classes in the mother tongues and cultures of the children of immigrants in primary schools, and also for the last few years in secondary schools. Funds for this are provided by the Ministry and the country of origin of the language, as well as the parents of the students who attend these lessons. The country whose language is taught and/or parents pay the teacher. The Ministry provides an annual lump sum per student attending extracurricular classes.

In recent years, primary schools have also been offering immigrant language lessons in the shape of compulsory elective subjects within regular classes in grades 7-9. The elective language subjects are aimed at all the pupils, not just children of immigrants. Data about the number of pupils who chose a foreign language as their elective subject show that between the school years 2005/06 and 2012/13 the number of children has fallen. The reasons for this decline should be further examined. One of the reasons for a lower interest of immigrant children in these subjects might be the fact that immigrant languages are in this case taught as foreign languages and, as noted by Požgaj-Hadži and Balažic-Bulc (2005: 38), "the teachers teaching this subject are in no way trained for teaching native speakers."

In the recent past, many schools did not even consider lessons in immigrant languages. They claim there was no interest, that they received no suggestions from parents or children, and lacked suitable teaching personnel even if such suggestions had arisen. Head teachers believe that pupils are much more interested in learning the "world" languages, such as English, 
French, and Spanish, while the "Yugoslav" languages are not as attractive to them (Komac et al., 2007: 229-230).

\section{Perceptions of immigrants, their descendants and of teachers about lessons in immigrant languages}

The aim of the surveys we carried out was to establish where immigrants and their descendants learned their mother tongue, how good their knowledge of the language was, what were their wishes with regard to the preservation of their mother tongue, and what was their readiness to learn their mother tongue formally, be it in school or on courses outside school. We were also interested in the teachers' attitudes to teaching immigrant mother tongues.

In the PSIP I survey we asked immigrants and their descendants where they had learned their mother tongue. The highest proportion of immigrants had learned it at home $(63.5 \%)$ or at school in the country of origin $(43.4 \%)$. The highest proportion of the descendants of immigrants had also learned their mother tongue at home (75.9\%). The ITCNS survey confirmed the finding that immigrant children usually learn their mother tongue at home, from their parents. Some participants in the survey told us that they often talked to their children in their mother tongue, as that was frequently the only situation and environment in which children could learn it.

The majority of the 1163 participants in the PSIP I survey (55\%) replied positively to the question as to whether it would be good if the children learned their mother tongue. Only $14 \%$ of the participants maintained that it was not necessary and that knowledge of Slovene was more important. At the same time, $27 \%$ of the survey participants thought that knowledge of world languages such as English or German was more important and that, instead of their mother tongue, the children should learn those. It should be emphasized here that among the participants from the younger generation (up to the age of 30) the proportion of those who supported the learning of the mother tongue was as high as $70 \%$. Learning the mother tongue was supported by a higher proportion of participants with higher levels of education.

The PSIP I participants were also asked about their views on the most suitable way the children whose mother tongue is not Slovene should be taught their mother tongue. A third of survey participants (33\%) thought that children could learn the language at home. Half the participants believed that children should have an opportunity to learn a (non-Slovene) mother tongue at school, either in the form of an elective subject within the regular program (22\%) or as an extracurricular activity (27\%). Eleven percent were of the opinion that children should learn immigrant languages within the framework of societies organized by immigrant communities. Two percent of the participants advocated the establishment of ethnic schools. The possibility of bilingual schooling was not offered as an option in the questionnaire so we cannot asses the immigrants' attitudes toward this form of mother-tongue learning.

Frequently - as shown also by the findings of the PSIP I - the descendants of immigrants have fairly well-developed listening and speaking skills in their mother tongue, but do not have such good writing skills. Many are motivated to learn and improve their language proficiency. A desire among a large proportion of immigrants and their descendants to learn or improve their mother tongue has also been noted by other studies in Slovenia (Požgaj-Hadži and Medica, 1997; Žitnik Serafin, 2008: 149). In view of this, the limited interest shown by pupils in learning these languages in the form of elective subjects or extracurricular activities in school might at a first glance seem surprising. However, the decision to learn their mother tongue in school depends not only on the personal wishes of pupils and their parents, but is strongly connected to other, external factors, such as peer pressure, stigmatization of the language, ${ }^{6}$ etc. Moreover, we should not neglect the fact that among the most important factors for integration into the Slovene society immigrants and their descendants mentioned: knowledge of Slovene, 
employment, and acquiring Slovene citizenship. Thus, it is not unusual that among immigrants and their descendants there are also some who do not feel a need for the formal learning of their mother tongue and are convinced that children learn it sufficiently at home or within the framework of the immigrant community (society, church, etc.), while in school they give priority to learning Slovene and other (world) languages. The PSIP I also shows that such a standpoint is supported by a higher proportion of those with a lower level of education, while support for learning mother tongues increases with the level of education.

It is worth mentioning here that the discrepancy between the majority of immigrants and their descendants who expressed a desire to learn the mother tongue and the small proportion of those who actually did something for the preservation of their language is characteristic not only of Slovenia. Surveys elsewhere have observed a similar situation (Glenn and De Jong, 1996: 251; Nusche et al., 2010: 36). Immigrants in Slovenia are not offered an opportunity for mother-tongue-based bilingual education. Nevertheless, they have the opportunity to learn their mother tongue either as an extracurricular activity or (for some immigrant languages) as an elective subject within the regular school program, though only in the last cycle of primary school and as a foreign language. This does not guarantee immigrant pupils all the advantages brought by education in the mother tongue mentioned at the beginning of this article. It is therefore understandable that, in this situation, immigrants prefer to learn other, world languages, because they see a greater benefit. We could also say that neither parents nor children nor, in fact, teachers are acquainted with the advantages of learning and being educated in the mother tongue, and consequently cannot make an informed decision about the greatest benefit for the children. Our research has shown that there is a desire for the preservation of immigrant mother tongues, but due to the lack of information on the importance of a mother tongue and the lack of available possibilities for learning, let alone being educated in it, many immigrants and their descendants have in a way accepted the existing situation and shifted to the language of the mainstream society. As Robinson (2005: 17) argues, "multilingual approaches must be shown to be feasible and to work - nobody wants to buy into something they have never seen or perhaps do not believe possible."

The study carried out during the drawing up of the White Paper on Education in Slovenia showed that most surveyed teachers and parents did not see a need for the organization of additional lessons in the mother tongues of immigrant children (Ministry of Education and Sport, 2011: 139). The ITCNS survey reached similar conclusions. There are individual teachers at some schools who try hard to include immigrant languages and knowledge about the culture of immigrant children into regular lessons in different subjects. This is certainly welcome from the viewpoint of encouraging children's positive self-image and self-respect, but cannot replace learning the mother tongue or being educated in it.

Reasons often given for not organizing lessons in the immigrant mother tongues are financial and organizational problems, and the lack of suitable personnel. The situation differs from school to school, depending on which language is at stake. Some teachers also perceive the use of the mother tongue by immigrant children as an obstacle to learning Slovene. However, studies and the academic literature do not support this belief (Paneque, 2006: 1). Some teachers advocate the use of the official (host country's) language instead of the immigrants' mother tongues in their communication at home. Paneque (2006: 171) argues that such advice to immigrant families is misguided and - though well intended-stems from misunderstandings about the nature of bilingualism and the process of language acquisition. Building on her advice, we could recommend that, instead of telling immigrant families to stop using their native languages and speak only the language of the host country, immigrants should be offered enough and adequate opportunities for language and cognitive development in both languages (Paneque, 2006: 173). 


\section{Concluding thoughts}

A mother tongue is more than a means by which individuals communicate with the world around them. Through this language, individuals learn about the world, they develop a way of thinking and expressing their thoughts and feelings. The mother tongue is very much tied to the culture to which it belongs and represents an important element of an individual's identity. Its preservation and development among immigrants and their descendants involves not only the preservation of the language as a means of communication, but also the preservation and affirmation of the individual's identity, the facilitation of maximum cognitive development and use of the individual's potential, and - as some research indicates - also the encouragement for quicker and easier learning of foreign languages.

Slovenia's current language policy supports in principle the preservation of immigrant languages in individual fields (education, culture); it offers legal guarantees for the formal possibility of learning and using the immigrant languages; but in spite of this, the legal protection of immigrant languages is much weaker in comparison to the legal protection of the linguistic rights of the traditional ethnic minorities. In addition, the actual realization of this right for immigrants in practice is relatively weak. Immigrants and their descendants who, at a personal level - as shown by our empirical research - support and express the need to learn their mother tongue, prefer to learn other foreign languages within the educational system, or strive toward learning Slovene as soon and as well as possible. The reasons for this are complex, from stigmatization of certain immigrant languages to the fact that the current opportunities for learning immigrant languages in the educational system are not offered in an appropriate manner. A certain proportion of the public and a considerable number of teachers still view the encouragement of the learning, preserving and developing of immigrant languages as an obstacle to successful integration. In this article we have presented some arguments that highlight the importance and advantages of immigrants learning their mother tongue and especially of being educated in it (while simultaneously learning the language of the host country). We are well aware that there is no agreement on this subject and that there are different objections raised by the opponents of bilingual education, ranging from the nonvalidity of the research that shows the favorable results of bilingual education to the nonfeasibility of its implementation in practice (too expensive, too many different languages, not enough teachers, etc.). Nevertheless, we argue that no analysis has been carried out in Slovenia that would explore the costs and benefits of bilingual education for immigrant children. Considering the fact that there are visible negative effects of the current educational policy that does not provide the equality of opportunities for immigrant children we believe it would be worthwhile exploring the possibility of a change of policy, including the consideration of introducing bilingual education for immigrant children. In addition to this, it would be good if more attention were given to providing information to the public - the majority society, as well as immigrants and their descendants - about the wider importance and (practical) value of immigrant languages. We believe that, not only immigrant communities, but the whole society could profit from multilingual education and the preservation of immigrant languages. A reconsideration of educational policy might also add to the discussion on the existing policy of differentiation between traditional and immigrant communities that at least with regard to language issues appears to be obsolete and does not provide adequate answers to the increasing linguistic diversity in the country. 


\section{Notes}

1. The few texts that touch upon this theme are: Ivanjko, 2007; Komac et al., 2007; KržišnikBukić, 2011; Medvešek and Bešter, 2010; Roter, 2007; Sinjur et al., 2012; Vižintin, 2010.

2. The terms "immigrant languages" and "languages of immigrants" in this article mean the mother tongues of people who have moved to Slovenia from other countries and their descendants living in Slovenia.

3. In the census methodology, the mother tongue was defined as the language a person learned in early childhood within the framework of the family or other primary environment. If a person has learned a number of languages in early childhood, the mother tongue is the one the person considers to be his or her mother tongue (SORS, 2002).

4. For more on this, see Krashen, 1996.

5. More information about these surveys can be found in research reports, scholarly articles, and other publications that were written on the basis of the results of these surveys (e.g. Komac, 2007; Komac et al., 2007; Medvešek and Bešter, 2010).

6. Due to the similarities of the languages of Croats, Serbs, Muslims, and Montenegrins in the former Yugoslavia the so-called Serbo-Croatian language was considered a common language of the majority of the Yugoslav population and it had privileged status in the school system as well as in other public domains. After Slovenia's independence the Serbo-Croatian language in Slovenia was stigmatized, representing all the unwanted elements of the former country that Slovenia wished to leave. And the negative image of this language was transferred to all the languages that emerged from it and were later standardized as official languages of the newly formed countries in the territory of the former Yugoslavia (Kržišnik-Bukić , 2011: 128).

\section{References}

Ball J (2011) Enhancing learning of children from diverse language backgrounds: Mother tongue-based bilingual or multilingual education in the early years. In: Paper commissioned for UNESCO. Available at: http://unesdoc.unesco.org/images/0021/002122/212270e.pdf (accessed 13 February 2013).

Baltić A (2010) Integracija bošnjaške skupnosti v Sloveniji. In: Medica K, Lukič G and Bufon M (eds) Migranti v Sloveniji-Med Integracijo in Alienacijo. Koper: Univerza na Primorskem, Znanstveno-raziskovalno središče, Univerzitetna založba Annales: Zgodovinsko društvo za južno Primorsko, pp.147-157.

Bauböck R (2002) Cultural minority right in public education: Religious and language instruction for immigrant communities in Western Europe. In: Messina A (ed.) West European Immigration and Immigrant Policy in the New Century. Westport: Praeger Publication, pp.161-190.

Blackledge A and Creese A (2009) 'Because tumi Bangali': Inventing and disinventing the national in multilingual communities in the UK. Ethnicities 9: 451-476.

Broeder P and Extra G (1999) Language, Ethnicity and Education. Case Studies on Immigrant Minority Groups and Immigrant Minority Languages. Clevedon: Multilingual Matters.

Christensen G and Stanat P (2007) Language Policies and Practices for Helping Immigrants and Second-Generation Students Succeed. Washington: Migration Policy Institute and Bertelsmann Stiftung. Available at: http://www.migrationpolicy.org/pubs/ChristensenEducation091907.pdf (accessed 15 February 2013).

Commission of the European Communities (1994) Report on the education of migrants' children in the European Union. $\operatorname{COM}(94) 80$ final, 25. 3. 1994, Available at: 
http://aei.pitt.edu/1257/01/migrant_children_COM_94_80.pdf (accessed 18 April 2014).

Coulmas F (1992) Language and Economy. Oxford, Cambridge: Blackwell.

Cummins J (2000) Language, Power and Pedagogy: Bilingual Children in the Crossfire. Clevedon, Buffalo, Toronto, Sydney: Multilingual Matters Ltd.

Cummins J (2001) Bilingual children's mother tongue: Why is it important for education? Sprogforum 7: 15-20.

Della Porta D and Keating M (2008) Approaches and Methodologies in the Social Sciences: A Pluralist Perspective. Cambridge, UK; New York: Cambridge University Press.

Eastman C (1984) Language, ethnic identity and change. In: Edwards J (ed.) Linguistic Minorities, Policies and Pluralism. London: Academic Press, pp.259-276.

Edwards J (1985) Language, Society and Identity. Oxford: Basil Blackwell Ltd; London: Andre Deutsch.

Edwards J (1994) Multilingualism. London: Routledge.

Elementary School Act. Uradni list Republike Slovenije, No. 81/2006-UPB, 102/2007, 107/2010, 87/2011.

Extra G and Yağmur K (2004) Multidisciplinary perspective. In: Extra G, Yağmur K (eds) Urban Multilingualism in Europe: Immigrant Minority Languages at Home and School.

Clevedon, Buffalo: Multilingual Matters, pp.11-24.

Fishman JA (1991) Reversing Language Shift: Theoretical and Empirical Foundations of Assistance to Threatened Languages. Clevedon, Philadelphia, Adelaide: Multilingual matters Ltd.

Fishman JA (2001) If threatened languages can be saved, then can dead languages be revived? Current Issues in Language Planning 2: 222-230.

Glenn CL and De Jong EJ (1996) Educating Immigrant Children: Schools and Language Minorities in Twelve Nations. New York and London: Garland Publishing, Inc.

Hajer M and Meestringa T (1991) Curriculum development in migrant languages and cultures at primary school level. In: Jaspaert K, Kroon S (eds) Ethnic Minority Languages and Education. Amsterdam: Swets \& Zeitlinger.

Isajiw WW (1993) The Assimilation-Retention Hypothesis and the Second and Third Generations. Toronto: University of Toronto Research Repository, Bioline

International Legacy Collection. Available at: http://hdl.handle.net/1807/70 (accessed 18 April 2014).

Ivanjko Š (2007) Odprta vprašanja pripadnikov novodobnih manjšin v zvezi z učenjem maternega jezika in razvoj lastne kulture. In: Devetak S (ed.) Zgodba o uspehu s priokusom grenkobe - diskriminacija v Sloveniji. Maribor: ISCOMET, pp.55-61.

Kertzer DI and Arel D (2002) Census and Identity. The Politics of Race, Ethnicity and Language in National Censuses. Cambridge, New York: Cambridge University Press.

Kolednik A (2010) Podatki raziskave PISA 2006: Primerjava dosežkov dijakov priseljencev in naravnih govorcev. Sodobna pedagogika 61: 136-154.

Komac M (2007) Varstvo 'novih' narodnih skupnosti v Sloveniji. In: Komac M (ed.) Priseljenci. Ljubljana: Ins`titut za narodnostna vprašanja, pp.35-65.

Komac M and Medvešek M (eds) (2005) Percepcije slovenske integracijske politike. Zakljucčo poročilo. Ljubljana: Institute for Ethnic Studies.

Komac M, Medvešek M and Roter P (2007) Pa mi vi povejte, kaj sem!!!? Študija o etnični raznolikosti v Mestni občini Ljubljana. Ljubljana: Fakulteta za družbene vede, Inštitut za narodnostna vprašanja.

Krashen S (1996) Under Attack: The Case Against Bilingual Education. Culver City: Language Education Associates.

Appendix.

Available

at: 
http://www.sdkrashen.com/articles/Comments_On_A_Recent_Critque.pdf (accessed 11 February 2013).

Krashen S (1997) Why bilingual education? ERIC digest. Available at: http://www.usc.edu/dept/education/CMMR/FullText/WhyBilingualEdKrashen.pdf (accessed 11 February 2013).

Kroon S (1990) Some remarks on ethnic identity, language and education. Innovation 3: 421435.

Kržišnik-Bukić V (2011) Statusno opredeljevanje in strokovna obravnava materinščin ex-yu populacij v slovenskem osnovnem šolstvu. Uporabno jezikoslovje 9-10: 124-142.

Lutz A (2007) Barriers to high-school completion among immigrant and later-generation Latinos in the USA: Language, ethnicity and socioeconomic status. Ethnicities 7: 323342.

Maalouf A, Limbach J, Pralong S, et al. (2008) A Rewarding Challenge, Proposals from the Group of Intellectuals for Intercultural Dialogue set up at the Initiative of the European Commission. Brussels: European Commission.

May S (2000) Uncommon Languages: The challenges and possibilities of minority language rights. Journal of Multilingual and Multicultural Development 21: 366-385.

May S (2008) Language and Minority Rights: Ethnicity, Nationalism and the Politics of Language. New York: Routledge.

May S (2011) Language rights: The 'Cinderella' of human rights. Journal of Human Rights 10: 265-289.

Medvešek M and Bešter R (eds) (2010) Državljani tretjih držav ali tretjerazredni državljani?: Integracija državljanov tretjih držav v Sloveniji. (Ethnicity 9), Ljubljana: Inštitut za narodnostna vprašanja.

Medvešek M and Bešter R (2011) Socio-ethnic school segregation in Slovenia. In: Bakker J, Denessen E, Peters D, et al. (eds) International Perspectives on Countering School Segregation. Antwerpen, Apeldoorn: Garant, pp.223-238.

Ministry of Education and Sport (2011) White Paper on Education in the Republic of Slovenia. Ljubljana: Educational Research Institute.

National Education Institute of the Republic of Slovenia (2009) Guidelines for the education of immigrant children in nurseries and schools. Available at: http://www.zrss.si/pdf/

270611133636_oekr_tujci_-_smernice_-_usklajeno_junij_doc_21_8_2009.pdf (accessed 4 February 2014).

National Education Institute of the Republic of Slovenia (2012) Guidelines for the inclusion of immigrant children into nurseries and schools. Available at: http://portal.mss.edus.si/msswww/programi2012/programi/media/pdf/smernice/cistopi s_Smernice_vkljucevanje_otrok_priseljencev.pdf (accessed 24 February 2013).

Novak Lukanovič S (2000) Pogled na dvojezično vzgojo in izobraževanje. In: Nečak-Lük A, Boris J (eds) Medetnični odnosi in etnična identiteta v slovenskem etničnem prostoru.

Urejanje medetničnih odnosov v Lendavi. Ljubljana: Inštitut za narodnostna vprašanja, pp.149164.

Novak Lukanovič S (2010) Language diversity in Slovenia. In: Novak Lukanovič S (ed.) A Shared Vision: Intercultural Dialogue-A Global Paradigm to Promote Linguistic and Cultural Diversity. Ljubljana: Slovenian national commission for UNESCO and Institute for Ethnic Studies, pp.59-85.

Novak Lukanovič S and Limon D (2012) Language policy in Slovenia. Language, Culture and Curriculum 25: 27-39.

Nowak-Fabrykowski K and Shkandrij M (2004) Between languages and cultures: the triad of symbols in the world of an immigrant child. Multicultural education 12: 25-29. 
Nusche D, Wurzburg G and Naughton B (2010) OECD Reviews of Migrant Education: Denmark. Paris: OECD Publishing.

OECD (2006) Where Immigrant Students Succeed. A Comparative Review of Performance and Engagement in PISA 2003. Paris: OECD.

Organization and Financing of Education Act. Uradni list Republike Slovenije, No. 16/2007UPB5,. . . 34/2011.

Paneque OM (2006) Good intentions, bad advice for bilingual families. Childhood education 82: $171-174$.

Požgaj-Hadži V and Balažic-Bulc T (2005) Kam je izginila srbohrvaščina? Status jezika nekoč in danes. In: Stabej M (ed.) Večkulturnost v slovenskem jeziku, literaturi in kulturi: zbornik predavanj. Ljubljana: Center za slovenščino kot drugi/tuji jezik pri Oddelku za slovenistiko Filozofske fakultete, pp.30-39.

Požgaj-Hadži V and Medica K (1997) Hrvatski jezik u Sloveniji. In: DominiM(ed.) Hrvati u Sloveniji. Znanstveni skup, Zagreb, 20-21 June 1996. Zagreb: Institut za migracije I narodnosti, pp.359-371.

Robinson C (2005) Languages and literacies - a commissioned study for the 2006 EFA Global Monitoring Report. Paris: UNESCO. Available at: http://unesdoc.unesco.org/images/0014/001461/146104e.pdf (accessed 29 July 2014).

Rossell C and Baker K (1996) The educational effectiveness of bilingual education. Research in the Teaching of English 30: 7-74. Available at: http://www.bu.edu/polisci/files/people/faculty/rossell/papers/effectiveness.pdf (accessed 12 February 2013).

Roter P (2007) Pomen in vloga jezika v integracijskem procesu. In: Komac M (ed.) Priseljenci. Ljubljana: Inštitut za narodnostna vprašanja, pp.301-331.

Resolucija o Nacionalnem programu za jezikovno politiko 2014-2018. Uradni list Republike Slovenije, No. 62/2013.

Schnepf SV (2004) How different are immigrants? A cross-country and cross-survey analysis of educational achievement. IZA Discussion Paper No. 1398.

Sinjur A, Devjak T, Blažič M, et al. (2012) Pupils with immigrant backgrounds—policies and practices of mother tongue tuition in Slovenia. Pedagoška obzorja 3-4: 170-183.

Šircelj M (2003) Verska, jezikovna in narodnostna sestava prebivalstva Slovenije: popisi 19212002, (Posebne publikacije, št. 2). Ljubljana: Statistišni urad Republike Slovenije. Available at: https://www.stat.si/doc/pub/sestava_preb_slo.pdf (accessed 30 July 2014).

Skutnabb-Kangas T (2004) The right to mother tongue medium education - the hot potato in human rights instruments. Opening plenary. In: II Mercator international symposium: Europe 2004: A new framework for all languages?, Tarragona-Catalunya. Available at: http://www.ciemen.org/mercator/pdf/simp-skuttnab.pdf (accessed 11 February 2013).

SORS - Statistical Office of the Republic of Slovenia (2002) Metodološka pojasnila in definicije, prebivalstvo. Available at: http://www.stat.si/popis2002/si/definicije_in_pojasnila_1.html (accessed 5 April 2014).

SORS - Statistical Office of the Republic of Slovenia (2011) Selitve, Slovenija, 1. Januar 2011-koncni podatki, 30 December 2011, Prva objava. Available at: http://www.stat.si/novica_prikazi.aspx?idL4430 (accessed 1 February 2013).

SORS - Statistical Office of the Republic of Slovenia (2014) Izvoz in uvoz po državah, Slovenija. Available at: http://pxweb.stat.si/sistat/MainTable/tbl_2401721 (accessed 20 March 2014).

Strategy of the inclusion of immigrant children, pupils and students into the education system in the Republic of Slovenia. Available at: http://www.mizs.gov.si/fileadmin/ mizs.gov.si/pageuploads/podrocje/razvoj_solstva/projekti/

Strategija_vkljucevanje_migrantov.doc (accessed 17 April 2013). 
Thomas WP and Collier VP (2002) A National Study of School Effectiveness for Language Minority Students' Long-Term Academic Achievement. Honolulu: Center for Research on Education, Diversity, and Excellence (CREDE). Available at: http://www.usc.edu/dept/education/CMMR/CollierThomasExReport.pdf (accessed 13 February 2013).

Tosi A (2004) Immigrant and ethnic minority languages in education: A summary of research findings and rationales relevant to a framework for European co-operation. Available at: http://p21208.typo3server.info/fileadmin/content/assets/eu_language_policy/action_pla n/Workshops/tosieucon_en.pdf (accessed 11 February 2013).

Trudell B, Dowd AJ, Piper B, et al. (2012) Early grade literacy in African classrooms: Lessons learned and future directions. A working document to serve as a basis for discussions at the Triennale Meeting of Association for the Development of Education in Africa (ADEA). Available at: http://www.adeanet.org/triennale/Triennalestudies/subtheme1/1_5_04_TRUDELL_en. pdf (accessed 18 April 2014).

Vižintin MA (2010) Pouk maternega jezika in kulture pri uc`encih priseljencih: temelj za medkulturni dialog v slovenski osnovni šoli? Sodobna pedagogika 1: 104-120.

Zavratnik S (2012) Migranti kot 'drugi': Refleksije mnenjskih merjenj. IB revija 46: 57-70.

Zavratnik Zimic S, Kralj A, Medarić Z, et al. (2008) Migracije, integracija in multikulturnostkontekstualizacije sodobnih migracij skozi javno mnenje: zaključno poročilo ciljnoraziskovalnega projekta 'Integracijske politike-vzpostavitev evalvacijskega modela in instrumentov longitudinalnega monitoringa'. Koper: Univerza na Primorskem, Znanstveno-raziskovalno središče.

Žitnik Serafin J (2008) Večkulturna Slovenija: Položaj migrantske književnosti in kulture v slovenskem prostoru (Migracije 15). Ljubljana: ZRC SAZU.

Žurnal24.si (2014) Zanesljivi srbski partnerji. Available at: http://www.zurnal24.si/zanesljivisrbski-partnerji-clanek-229563 (accessed 11 April 2014). 